\title{
Root Canal Irrigants in Primary Teeth
}

\author{
1Jaya Agali Ramachandra, ${ }^{2}$ Nidhi K Nihal, ${ }^{3} \mathrm{C}$ Nagarathna, ${ }^{4}$ Miloni S Vora
}

\begin{abstract}
The endodontic triad consists of cleaning and shaping, disinfection and obturation. Success of root canal therapy in primary teeth is mainly achieved by thorough removal of debris and necrotic tissue. However, complete elimination of bacterial contaminants as well as necrotic debris require adjunctive use of root canal irrigants along with mechanical instrumentation. As we know from literature that none of the available irrigating solutions alone provides all the ideal requirements. Studies have shown that a combination of two or more irrigating solutions in a specific sequence will help to achieve optimal irrigation. This review article mainly highlights the mechanism of action, safety and biocompatibility of currently used irrigation solutions and also the other materials that can be used as a potent irrigants, their advantages and limitations in future of endodontics.
\end{abstract}

Keywords: Antimicrobial properties, Primary teeth, Root canal irrigants, Smear layer.

How to cite this article: Ramachandra JA, Nihal NK, Nagarathna C, Vora MS. Root Canal Irrigants in Primary Teeth. World J Dent 2015;6(3):229-234.

Source of support: Nil

Conflict of interest: None

\section{INTRODUCTION}

Successful endodontic treatment requires combination of variety of factors, such as an accurate diagnosis, thorough cleaning, a predictable disinfection protocol achieved with the help of various intracanal medicaments and irrigation solutions followed by obturation of the pulp space and adequate final restoration. ${ }^{1}$ There exists anatomical differences between primary and permanent teeth with respect to size, internal and external morphology. ${ }^{2}$ Treating the primary teeth endodontically is considered highly complicated as the primary teeth exhibits bizzare internal geometry and other features like furcational connections and horizontal anastomoses which is uncommon in permanent teeth. ${ }^{3}$ The recent imaging

\footnotetext{
${ }^{1}$ Reader, ${ }^{2,4}$ Private Practitioner, ${ }^{3}$ Professor and Head

${ }^{1,3}$ Department of Pedodontics, Rajarajeswari Dental College and Hospital, Bengaluru, Karnataka, India

${ }^{2}$ Department of Pedodontics, Kolkata, India

${ }^{4}$ Department of Pedodontics, Gujarat, India
}

Corresponding Author: Jaya Agali Ramachandra, Reader Department of Pedodontics, Rajarajeswari Dental College and Hospital, Bengaluru, Karnataka, India, Phone: 08026931265 e-mail: jaya.vrushabh@gmail.com techniques showed that some part of the pulp spaces remain uninstrumented with the use of mechanical preparation alone. Hence, irrigation and instrumentation complement each other in complete debridement and disinfection of root canal. ${ }^{4}$ In primary tooth root canal infections, the largest number of microorganisms can be found in main root canal. However, a considerable portion of infection is located deeper, in the lateral canals, apical ramifications and dentinal tubules. In clinical practice instrumentation and irrigation of canal within endodontic treatment is time-consuming and the most demanding treatment phase in children. ${ }^{5}$

\section{ENDODONTIC MICROBIOLOGY OF PRIMARY TEETH}

The microorganisms associated with endodontic infections comprises of a complex mixture of bacterial species. It has been reported that the root canal microbiota recovered from asymptomatic teeth is different from that isolated from clinically symptomatic teeth. ${ }^{6}$ Both aerobic and anaerobic microorganisms as well as facultative microorganisms can be found in the primary root canal. Cogulu et al found that the most prevalent species of bacteria in primary teeth root canal were Enterococcus faecalis, Porphyromonas gingivalis and Treponema denticola. ${ }^{7,8}$ Although E. faecalis is occasionally found in the initial root canal infections in permanent teeth, it was found to be present in $63 \%$ of the necrotic primary teeth. Necrotic teeth are clinical features commonly seen in early childhood caries, a form of dental caries largely prevalent in children. ${ }^{9} \mathrm{Hu}$ et al isolated 240 strains of bacteria from 22 infected primary root canal. Among 240 strains, 200 strains were obligate anaerobes, belonging to genera Peptostreptococcus, Bacteroides, Veillonella, Eubacterium, Propionibacterium, Actinomyces and Fusobacterium. Bacteroides and Fusobacterium especially P. gingivalis and F. nucleatum probably were related to acute periapical inflammation and Veillonella parvula from chronic periapical inflammation of primary teeth. ${ }^{10}$

\section{ROOT CANAL IRRIGANTS}

The currently used irrigants can be grouped into antibacterial and decalcifying agents or their combinations. Two or more irrigating solutions in a specific sequence contributes to a successful treatment outcome as no single 
irrigating solution is regarded optimal. And the ideal requisites of root canal irrigants are:

- Should possess broad antimicrobial spectrum

- High efficiency against anaerobic and facultative microorganisms organized in biofilm

- Completely dissolve necrotic pulp tissue remnants

- Inactivate endotoxins effectively

- Should be able to avoid formation or dissolve smear layer that has formed during instrumentation

- Should be nontoxic to vital tissues, non caustic to periapical and periodontal tissues when accidently injected beyond apex, and with little or no potential to cause anaphylactic reactions. ${ }^{11}$

\section{SODIUM HYPOCHLORITE}

Sodium hypochlorite $(\mathrm{NaOCl})$ is the most commonly used irrigating solution. Sodium hypochlorite gives rise to sodium and the hypochlorite ion when combined with water thereby establishing an equilibrium with hypochlorous acid which is responsible for the antibacterial activity of $\mathrm{NaOCl}$. It acts on microbial cells disrupting the most vital functions of the cell leading to the cell death. ${ }^{12,13}$ Sodium hypochlorite when used in concentration of $0.5 \%$ (most commonly used) acts as a potent antimicrobial agent killing the bacterias instantly. It also has the ability to dissolve the organic components of dentin such as pulpal remnants and collagen. The only limitation of hypochlorite is that its inability to remove the smear layer, however when canals were subsequently irrigated with ethylenediaminetetraacetic acid (EDTA) or citric acid (CA) following $\mathrm{NaOCl}$ irrigation it has shown to effect organic portion of the smear layer thereby leading to its complete removal. ${ }^{14} \mathrm{~A}$ comparative study done to evaluated the effectiveness of $\mathrm{NaOCl}(0.5 \%$ or $5 \%$ with or without EDTA and saline when used as root canal irrigants in necrotic canals with anaerobic bacteria showed considerable reduction of bacterial counts in the canal when compared with canals irrigated only with saline. However, it was difficult to render the canals completely free from bacteria, even after repeated sessions. ${ }^{15,16} \mathrm{~A}$ study compared saline and $\mathrm{NaOCl}$ in its ability to remove smear layer in primary teeth which showed $\mathrm{NaOCl}$ was better than saline, although it partially removes smear layer. ${ }^{17}$ Another study showed when $6.0 \%$ CA is used in association with hypochlorite as auxiliary chemical substances for irrigating primary teeth has remarkable effect on smear layer removal of primary molars. ${ }^{18}$

Though $\mathrm{NaOCl}$ is a commonly used root canal irrigant, it has an unpleasant odor and taste; it does not consistently disinfect the root canal system and is toxic when extruded into the periradicular tissues. It can damage permanent tooth follicles, peripheral tissues and oral mucosa. ${ }^{19}$

\section{CHLORHEXIDINE}

Endodontic literature has shown that chlorhexidine (CHX) is used at $2 \%$ concentration as root canal irrigating solution it, reacts with negatively charged groups on the cell surface, thereby showing greater reduction of intracanal bacteria compared with sterile saline solution. ${ }^{20}$ This is thus suggested as an alternative for pulpectomy of necrotic primary teeth. ${ }^{21}$ Though CHX as a root canal irrigant has not shown any long-term damage to host tissues, inflammatory responses were expressed from the host tissues when it was accidently injected beyond the root apex. Though CHX is considered as a potent irrigating solution, its ineffectiveness on removal of necrotic remnants and limited action on Gram-negative organisms compared to Gram-positive bacteria it cannot be used as a final irrigant in endodontic cases. ${ }^{22}$

\section{ETHYLENEDIAMINETETRAACETIC ACID AND CITRIC ACID}

Ethylenediaminetetraacetic acid is most commonly used as $17 \%$ neutralized solultion. Citric acid is made available in various concentrations from 1 to $50 \%$, although $10 \%$ CA is more commonly used as it is effective in removal of the smear layer. Ethylenediaminetetraacetic acid and CA are available as liquids and gels. ${ }^{23}$ They effectively dissolve the inorganic component and smear layer with little or no effect on organic tissue.

However, they themselves do not possess any antibacterial activity. ${ }^{24,25}$ Though smear layer removal was better when EDTA was used in combination with sodium hypochlorite damage to the dentinal tubules, peritubular dentin erosion and disruption of intertubular dentin was found. ${ }^{17}$ Studies have shown irrigation with $6 \% \mathrm{CA}$ for 15 or 30 seconds is quite effective in removing all the components of the smear layer of the primary teeth whereas peritubular dentin destruction was observed when higher concentration of CA was used as an irrigating solution. ${ }^{17,18,26}$

\section{MIXTURE OF DOXYCYCLINE, CITRIC ACID AND A DETERGENT}

Mixture of doxycycline, citric acid and a detergent Torabinejad et al introduced MTAD which is a mixture of $3 \%$ doxycycline, $4.25 \%$ and detergent-Tween 80 . It has been as an alternative to EDTA which removes the smear layer effectively when used as a final rinse to disinfect the root canals of primary teeth. It also possesses antibacterial and chelating properties. ${ }^{27}$ 
Various studies have shown that MTAD was effective in removal of smear layer without causing any significant changes in the structure of dentinal tubules when used as a final rinse followed by irrigation with $\mathrm{NaOCl}$. Mixture of doxycycline, citric acid and a detergent also exhibited superior antimicrobial efficacy (statistically significant decrease of E. faecalis, P. intermedia and T. forsythenis) compared with $2.5 \% \mathrm{NaOCl}, 17 \%$ EDTA and $2 \% \mathrm{CHX}$ and also shown to eliminate bacteria in human root canals that had been infected by whole saliva. ${ }^{28}$ MTAD solution as the final irrigant has shown to meet all the standards for good irrigant prescribed. It proves it to be an effective irrigant for the primary teeth. Studies have shown that MTAD is less cytotoxic compared to other endodontic medicaments such as eugenol, hydrogen peroxide (3\%), EDTA. ${ }^{3,19}$ However the use of MTAD in primary teeth is limited because of chance of discoloration in permanent buds present below. However, its use in young permanent teeth may not be controversial. ${ }^{19}$

\section{TETRACLEAN}

Tetraclean, is a mixture of an antibiotic, an acid (citric acid), and a detergent(polypropylene glycol). The concentration of citric acid and the type of detergent used varies from that of MTAD. ${ }^{29}$ The properties of tetraclean is due to its low surface tension which enables better adaptation of the mixtures to the dentinal walls. It removes the smear layer, effective against strictly anaerobic and facultative anaerobic bacteria like E. faecalis. ${ }^{30}$

\section{CARISOLV}

Carisolv contains $0.5 \%$ sodium hypochlorite along with amino acids. Thus it was hypothesized that this agent can also be effective in removal of smear layer in root canal when used as an irrigant. The mode of action is to degrade the denatured collagen. A study which compared Carisolv with 17\% EDTA and 5.25\% sodium hypochlorite in removing layer on radicular dentin showed that Carisolv was ineffective in removal of smear layer. The reason attributed was because it was in gel form which made it difficult to wet and flush the canals. ${ }^{31}$ However, very little evidence is available in literature. A study was done to compare the efficacy of Carisolv, $1 \% \mathrm{NaOCl}$ gel, and $1 \% \mathrm{NaOCl}$ solution as root canal irrigants in primary teeth showed that Carisolv was better compared to $\mathrm{NaOCl}$ gel in cleaning the debris at the apical third. And hence concluded that Carisolv can be used as an effective root canal irrigant. ${ }^{32}$

\section{ELECTROCHEMICALLY ACTIVATED SOLUTIONS}

A mixture of tap water and low concentrated salt solutions forms the electrochemically activated (ECA) which results in synthesis of Anolyte, and Catholyte. The oxydizing substances of anolyte exhibits microbicidal activity against bacteria, viruses, fungi and protozoa and therefore termed Superoxidized Water or Oxidative Potential Water. Due to its various advantages like ease of removal of debris and smear layer even at the apical third as well as its nontoxic properties it can be used as a potent root canal irrigant. A study showed that OPW was as effective as the $\mathrm{NaOCl}$ when used as an irrigant in necrotic pulpectomized primary teeth and is suggested as an alternative for irrigating primary teeth. ${ }^{33}$

\section{OZONATED WATER}

Ozone is a chemical compound consisting of three oxygen atoms (O3-triatomic oxygen), which has higher energetic form than normal atmospheric oxygen. Ozone is capable of oxidizing any biological entity due to its powerful bactericidal properties where even at low concentration, $(0.1 \mathrm{ppm})$, it is capable of inactivating bacterial cells including their spores. ${ }^{3}$ Although it is a powerful antimicrobial agent, less attention has been paid to its antibacterial activity on bacterial biofilm and hence in root canal infection. ${ }^{34,35}$ Studies have found that when the specimen was irrigated with sonication killing ability of ozonated water and $2.5 \%$ sodium hypochlorite was almost comparable, However, it was found that effect on E. faecalis was more with $\mathrm{NaOCl}$ than ozonated water in broth culture and in biofilm. Hence concluded that there is need for further studies and modifications in ozonated water before it could be used as a root canal irrigant. ${ }^{3}$ Photon activated disinfection. Photon activated disinfection is based on the concept where light of the appropriate wavelength is used to preferentially localize the nontoxic photosensitizers to generate singlet oxygen and free radicals that are cytotoxic to cells of the target tissue. ${ }^{36}$ Blue dyes, especially toluidine blue and methylene blue used with a $632.8 \mathrm{~nm}$ wavelength laser have shown significant result. A study in primary teeth showed a microbial reduction of $98.37 \%$ after using photodynamic therapy. ${ }^{37}$ The literature highlights PDT in endodontic treatment of permanent teeth unlike primary teeth. Thus in future PAD could be a low-cost and nontraumatic alternative to other irrigants to be used in today's treatment of primary teeth.

\section{HERBAL IRRIGANTS}

The use of herbal products in the field of medicine has been practiced since ancient times and has significantly increased over the last few decades. In recent endodontics because of the limitations of most of the commercial intracanal medicaments used such as cytotoxicity and 
their inability to eliminate bacteria from dentinal tubules, trend of recent medicine to use biologic medication extracted from natural plants is drawing a lot of attention. The major advantages of using herbal alternatives are easy availability, cost-effectiveness, increased shelf life, low toxicity, and lack of microbial resistance reported. Literature has shown that herbs can have a promising role as root canal irrigants.

\section{MISWAK}

Miswak is derived from the plant Salvadora persica (known asÿarakÿ in Arabic) mainly used as a chewing stick, which is used for cleansing the teeth. ${ }^{38}$ Wolinsky and Sote, by isolation of the active ingredient from $S$. persica, found that the limonoid had a great antimicrobial activity by inhibiting the growth of various Gram-positive and Gram-negative microorganisms by interfering extrapolysaccharides and glycosidase enzymes produced by these microorganisms. ${ }^{39}$ An in vitro study showed that 10 to $20 \%$ miswak extract was effective antifungal and antibacterial agent when used as an irrigant in the endodontic treatment of teeth with necrotic pulps against Candida albicans and E. fecalis. A study done on primary teeth showed that for root canal irrigation miswak could be a good natural substitute to sodium hypochlorite. ${ }^{40}$

\section{MORINDA CITRIFOLIA}

Morinda citrifolia commercially known as Noni or Indian Mulberry, has a broad range of therapeutic effects such as antibacterial anti-inflammatory, antiviral, antitumor, anthelmintic, analgesic, hypotensive, anti-inflammatory and immune enhancing effects might be advantageous.

Due to its properties and not likely to cause the severe injuries to patients that might occur through $\mathrm{NaOCl}$ accidents its juice can be used as a potent irrigant in primary teeth. ${ }^{41}$ The antimicrobial activity on E. faecalis of $2 \% \mathrm{CHX}$ gel, propolis, $M$. citrifolia juice and $\mathrm{Ca}(\mathrm{OH})_{2}$ has been compared. It was concluded that Propolis and $M$. citrifolia were effective against $E$. faecalis in dentin on extracted teeth. ${ }^{42}$ Study has also shown that MCJ had anticandidal activity in vitro. ${ }^{43}$

\section{TRIPHALA AND GREEN TEA PHENOLS}

Triphala is one of the well known Indian Ayurvedic herbal formulation consisting of dried and powdered fruits of three medicinal plants namely Terminalia bellirica (Gaertn) Roxb, Terminalia chebula Retz and Emblica officinalis Gaertn. ${ }^{3,44}$ Green tea polyphenolsNumerous human, animal and in vitro studies have shown anticariogenic, anti-inflammatory, thermogenic, probiotic and antimicrobial properties. ${ }^{41}$ An in vitro study showed maximum antibacterial activity with $\mathrm{NaOCl}$ and statistically significant antibacterial activity with Triphala, GTPs, MTAD and 5\% hypochlorite against $E$. faecalis biofilm. ${ }^{44}$

\section{GERMAN CHAMOMILE AND TEA TREE OIL}

German chamomile is a medicinal plant known for its anti-inflammatory, analgesic, anti-microbial, antispasmic and sedative properties. Chamomile was found to be effective when used as a mouthwash and many properties such as antiseptic, antifungal agent and a mild solvent. ${ }^{41}$ An SEM study done on German chamomile extract and tea tree oil as irrigants and showed that efficacy of chamomile to remove smear layer was superior to $\mathrm{NaOCl}$ alone but less than $\mathrm{NaOCl}$ combined with EDTA. ${ }^{45}$

\section{PROPOLIS}

Propolis, a resinous beehive product is a potent antimicrobial, antioxidant and anti-inflammatory agent. ${ }^{19}$ Very few studies have evaluated propolis as a root canal irrigant. Comparative evaluation of antimicrobial activity of miswak, propolis, sodium hypochlorite and saline as root canal irrigants by microbial culturing and quantification in chronically exposed primary teeth was done showed that results of propolis was comparable to those of the negative control. ${ }^{40}$ An in vivo randomized trial was conducted where root canals were irrigated using either $2 \%$ CHX, $4 \%$ calcium hydroxide or DMSO) extract of propolis with normal saline as the control irrigant. Which showed a significant decrease in mean aerobic colony forming units count in all the groups, however CHX was superior. ${ }^{46}$ Propolis has also shown to be an effective intracanal irrigant in eradicating E. faecalis and C. albicans. ${ }^{47-50}$

\section{CONCLUSION}

Elimination of microorganisms from infected root canals of primary teeth is a complicated task. The chances of a favorable outcome with root canal treatment are significantly high if infection is eradicated effectively before obturation. Hence irrigating solutions play a key role in the success of endodontic treatment of primary teeth.

\section{REFERENCES}

1. Peters OA, Schönenberger K, Laib A. Effects of four NiTi preparation techniques on root canal geometry assessed by micro computed tomography. Int Endod J 2001;34(3):221-230.

2. Aminabadi NA, Farahani RM, Gajan EB. Study of root canal accessibility in human primary molars. J Oral Sci 2008 Mar; 50(1):69-74. 
3. Jaju S, Jaju PP. Newer root canal irrigants in horizon: a review. Int J Dent Epub 2011;Nov 30.

4. Haapasalo M, Endal U, Zandi H, Coil JM. Eradication of endodontic infection by instrumentation and irrigation solutions. Endodontic Topics 2005;10(1):77-102.

5. Mitic A, Mitic N, Zivković S, Milasin J, Gasic J, Mitic V, et al. The importance of final irrigation with mineralolithic effect agents during chemomechanical treatment of tooth root canal. Oral Health Care-Pediat, Res, Epidemiol and Clinical Practices, Professor Mandeep Virdi, editors. Available at: www.intechopen.com 285-302.

6. Yoshida M, Fukushima H, Yamamoto K, Ogawa K, Toda T, Sagawa $\mathrm{H}$. Correlation between clinical symptoms on microorganisms isolated from root canals with periapical pathosis. J Endod 1987;13(1):24-28.

7. Rana V, Baba SM, Pandey A. Bacteriology of infected deciduous root canal: a review. People's J Scientific Res 2009 Jul;2(2):45-48.

8. Cogulu D, Uzel A, Oncag O, EronatC. PCR-based identification of selected pathogens associated with endodontic infections in deciduous and permanent teeth. Oral Surg Oral Med Oral Pathol Oral Radiol Endod 2008;106(3):443-449.

9. Oncag O, Cogulu D, Uzel A. Efficacy of various intracanal medicaments against Enterococcus faecalis in primary teeth: an in vivo study. J Clin Pediatr Dent 2006;30(3):233-238.

10. HuYw, Zhu M, Liu Z. A bacteriology analysis from infected root canals of human deciduous teeth. Shanghai J Stomatol 1998;7(3):143-146.

11. Zehnder M. Root canal irrigants. J Endod 2006 May;32(5): 389-398.

12. Barrette WC Jr, Hannum DM, Wheeler WD, et al. General mechanism for the bacterial toxicity of hypochlorous acid: abolition of ATP production. Biochemist 1989;28:9172-9178.

13. McKenna SM, Davies KJA. The inhibition of bacterial growth by hypochlorous acid. Biochem J 1988;254:685-692.

14. Mcdonnell G, Russell D. Antiseptics and disinfectants: activity action and resistance. Clin Microbiol Rev 1999;12: 147-179.

15. Bystrom A, Sundqvist G. Bacteriologic evaluation of the effect of $0.5 \%$ sodium hypochlorite in endodontic therapy. Oral Surg Oral Med Oral Pathol 1983;55(3):307-312.

16. Bystrom A, Sundqvist G. The antibacterial action of sodium hypochlorite and EDTA in 60 cases of endodontic therapy. Int Endod J 1985;18(1):35-40.

17. Hariharan VS, Nandlal B, Srilatha KT. Efficacy of various root canal irrigants on removal of smear layer in the primary root canals after hand instrumentation: a scanning electron microscopy study. J Ind Soc Pedod Prev Dent 2010 Oct-Dec; 28(4):271-277.

18. GotzeGda R, Cunha CB, Primo LS, Maia LC. Effect of the sodium hypochlorite and citric acid association on smear layer removal of primary molars. Braz Oral Res 2005 Oct-Dec; 19(4):261-266.

19. Nara A, Chandra DP, Anandakrishna L, Dhananjaya G. Comparative evaluation of antimicrobial efficacy of MTAD, $3 \% \mathrm{NaOCl}$ and propolis against E. Faecalis. Int J Clinic Ped Dent 2010 Jan-Apr;3(1):21-25.

20. Jones CG. Chlorhexidine: is it still the gold standard? Periodontol 1997;15(1):55-62.

21. Ruiz-Esparza CL, Garrocho-Rangel A, Gonzalez-Amaro AM, Flores-Reyes H, Pozos-Guillen AJ. Reduction in bacterial loading using $2 \%$ chlorhexidine gluconate as an irrigant in pulpectomized primary teeth: a preliminary report. J Clin Pediatr Dent 2011 Spring;35(3):265-270.

22. Khademi A, Sefian E, Mahboobe F. Tissue dissolving ability of several endodontic irrigants on bovine pulp tissue. Iran Endod J 2007 Summer;2(2):65-68.

23. Haapasalo $M$, Shen $Y$, Qian W, Gao Y. Irrigation in endodontics. Dent Clin North Am 2010 Apr;54(2):291-312.

24. Haapasalo $M, \varnothing$ rstavik D. In vitro infection and disinfection of dentinal tubules. J Dent Res 1987;66(8):1375-1379.

25. Ørstavik D, Haapasalo M. Disinfection by endodontic irrigants and dressings of experimentally infected dentinal tubules. Endod Dent Traumatol 1990;6(4):142-149.

26. Salama FS, Abdelmegid FY. Six percent citric acid better than hydrogen peroxide in removing smear layer: an in vitro pilot study. Pediatr Dent 1994 Nov-Dec;16(6):424-426.

27. Torabinejad M, Khademi AA, Babagoli J, Cho Y, Johnson WB, Bozhilov K. A new solution for removal of smear layer. J Endod 2003;29(3):170-175.

28. Shabahang $S$, Pouresmail M, Torabinejad M. In vitro antimicrobial efficacy of MTAD and sodium hypochlorite. J Endod 2003;29(7):450-452.

29. Giardino L, Ambu E, Becce C, Rimondini L, Morra M. Surface tension comparison of four common root canal irrigants and two new irrigants containing antibiotic. J Endod 2006;32(11): 1091-1093.

30. Giardino L, Savoldi E, Ambu E, Rimondini R, Palezona A, Debbia EA. Antimicrobial effect of MTAD, tetraclean, cloreximid and sodiumhypochlorite on three common endodontic pathogens. Ind J Dent Res 2009 Jul-Sep;20(3):391-395.

31. John BM, Acharya SR, Saraswathi V, Usha C. Comparative evaluation of carisolv with EDTA and sodium hypochlorite in removing the smear layer on radicular dentine using SEM: an in vitro study. J Scientific Dentist 2012;2(2):11-18.

32. Singhal P, Das UM, Vishwanathan D, Singhal A. Carisolv as an endodontic irrigant in deciduous teeth: an SEM study. Ind J Dent Res 2012 Jan-Feb;23(1):120-121.

33. Valdez-Gonzalez C, Mendez-Gonzalez V, Torre-Delgadillo G, Flores-Reyes H, Gaitan-Fonseca C, Pozos-Guillen AJ. Effectiveness of oxidative potential water as an irrigant in pulpectomized primary teeth. J Clin Pediatr Dent 2012 Fall; 37(1):31-35.

34. Nagayoshi M, Kitamura C, Fukuizumi T, Nishihara T, Terashita M. Antimicrobial effect of ozonated water on bacteria invading dentinal tubules. J Endod 2004;30(11): 778-781.

35. Ibrahim NZ, Abdullah M. Antimicrobial evaluation of sodium hypochlorite and ozonated water on E. faecalis biofilm. Annals of Dentist 2008;15(1):20-26.

36. Dougherty TJ, Gomer CJ, Henderson BW, et al. Photodynamic therapy. J National Cancer Institute 1998;90(12):889-905.

37. Pinheiro SL, Schenka AA, Neto AA, de Souza CP, Rodriguez HM, Ribeiro MC. Photodynamic therapy in endodontic treatment of deciduous teeth. Lasers Med Sci 2009 Jul;24(4):521-526.

38. Al-Obaida MI, Al-Essa MA, Asiri AA, Al-Rahla AA. Effectiveness of $20 \%$ miswak extract against a mixture of Candida albicans and Enterococcus faecalis. Saudi Med J 2010 Jun;31(6):640-643.

39. Talal H Al-Salman, MoatazGh Al-Shaekh Ali, Osama M Al-Nu'aimy. The antimicrobial effect of water extraction of Salvadorapersica (Miswak) as a root canal irrigant. AlRafidain Dent J 2005;5(1):33-36. 
40. Shingare P, Chaugule V. Comparative evaluation of antimicrobial activity of miswak, propolis, sodium hypochlorite and saline as root canal irrigants by microbial culturing and quantification in chronically exposed primary teeth. Germs 2013 Jun;3(2):67.

41. Pujar M, Makandar S. Herbal usage. In Endodontics: a review. IJCD 2011 Jan;2(1):34-37.

42. Ferreira FB, Torres SA, Rosa OP, Ferreira CM, Garcia RB, Marcucci MC, Gomes BP. Antimicrobial effect of propolis and other substances against selected endodontic pathogens. Oral Surg Oral Med Oral Pathol Oral Radiol Endod 2007 Nov; 104(5):709-716.

43. Tyagi SP, Sinha DJ, Garg P, Singh UP, Mishra CC, Nagpal R. Comparison of antimicrobial efficacy of propolis, Morinda citrifolia, Azadirachta indica (Neem) and 5\% sodium hypochlorite on Candida albicans biofilm formed on tooth substrate: an in-vitro study. J Conserv Dent 2013 Nov-Dec; 16(6):532-535.

44. Prabhakar J, Senthikumar M, Priya MS, et al. Evaluation of antimicrobial efficacy of herbal alternatives (Triphala and green tea polyphenols), MTAD, and 5\% sodium hypochlorite against enterococcus faecalis biofilm formed on tooth substrate: an in vitro study. J Endod 2010;36(1):83-86.
45. Sadr Lahijani MS, Raoof Kateb HR, Heady R, et al. The effect of german chamomile (Marticariarecutitia L) extract and tea tree (Melaleuca alternifolia L) oil used as irrigants on removal of smear layer: a scanning electron microscopy study. Int Endod J 2006;39(3):190-195.

46. Jolly M, Singh N, Rathore M, Tandon S, Banerjee M. Propolis and commonly used intracanal irrigants: comparative evaluation of antimicrobial potential. J Clin Pediatr Dent 2013 Spring;37(3):243-249.

47. Arslan S, Ozbilge H, Kaya EG, Er O. In vitro antimicrobial activity of propolis, BioPure MTAD, sodiumhypochlorite, and chlorhexidine on enterococcus faecalis and Candida albicans. Saudi Med J 2011 May;32(5):479-483.

48. Ghorbanzadeh S, Loodaricheh SA, Samizade S, Zadsirjan S. Irrigants in endodontic treatment. Int J Contemp Dent Med Rev, 2015. Article ID: 030515, 2015.

49. Sonarkar S, Purba R. Bioactive materials in conservative dentistry. Int J Contemp Dent Med Rev, 2015. Article ID: 340115, 2015.

50. Swetha B, Mathew S, Murthy BV, Shruthi N, Bhandi SH. Determination of biocompatibility: a review. Int Dent Med J Adv Res 2015;1(1):1-6. 